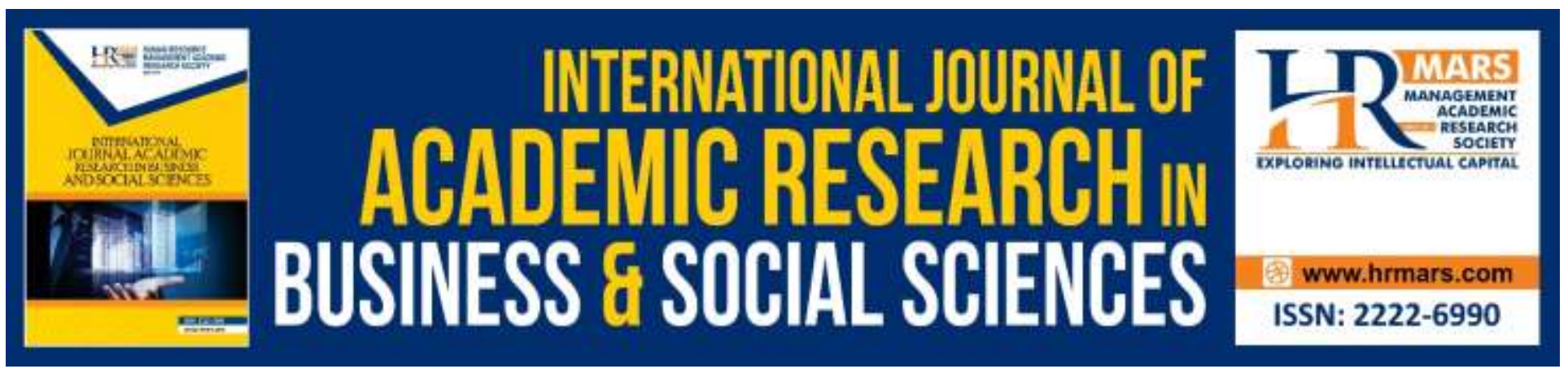

\title{
Determinant Factors for Employee Retention: Should I Stay?
}

Nomahaza Mahadi, Norliyana M.F. Woo, Shathees Baskaran and Azizul Yadi Yaakop

To Link this Article: http://dx.doi.org/10.6007/IJARBSS/v10-i4/7120

DOI:10.6007/IJARBSS/v10-i4/7120

Received: 25 February 2020, Revised: 28 March 2020, Accepted: 07 April 2020

Published Online: 14 April 2020

In-Text Citation: (Mahadi et al., 2020)

To Cite this Article: Mahadi, N., Woo, N. M. F., Baskaran, S., \& Yaakop, A. Y. (2020). Determinant Factors for Employee Retention: Should I Stay? International Journal of Academic Research in Business and Social Sciences, 10(4), 201-213.

Copyright: (C) 2020 The Author(s)

Published by Human Resource Management Academic Research Society (www.hrmars.com)

This article is published under the Creative Commons Attribution (CC BY 4.0) license. Anyone may reproduce, distribute, translate and create derivative works of this article (for both commercial and non-commercial purposes), subject to full attribution to the original publication and authors. The full terms of this license may be seen at: http://creativecommons.org/licences/by/4.0/legalcode

Vol. 10, No. 4, 2020, Pg. 201 - 213

http://hrmars.com/index.php/pages/detail/IJARBSS

Full Terms \& Conditions of access and use can be found at http://hrmars.com/index.php/pages/detail/publication-ethics 


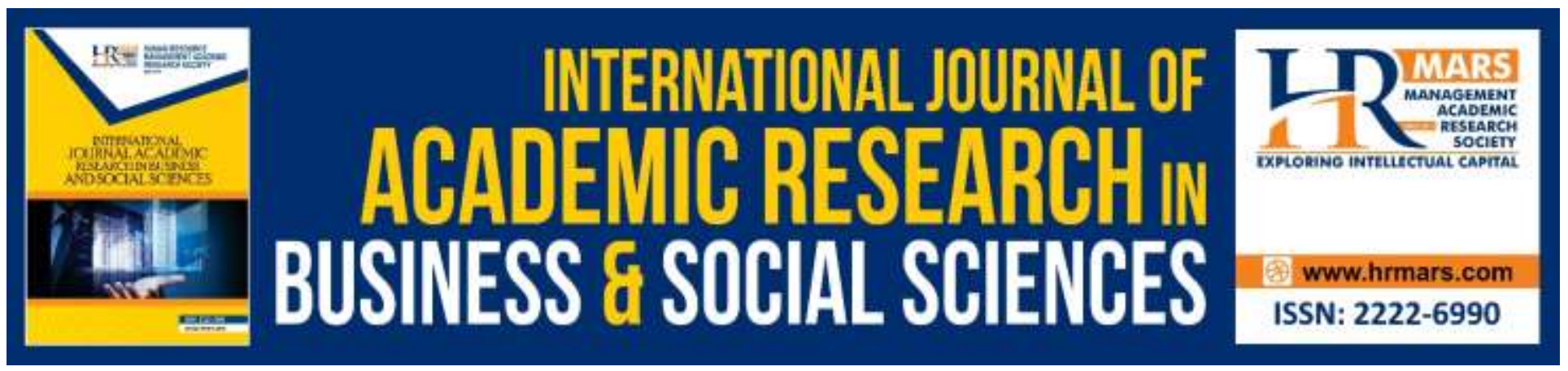

\title{
Determinant Factors for Employee Retention: Should I Stay?
}

\author{
Nomahaza Mahadi ${ }^{1}$, Norliyana M.F. Woo², Shathees Baskaran ${ }^{3}$ and \\ Azizul Yadi Yaakop 4 \\ 1,3 International Business School, Level 10, Menara Razak, Universiti Teknologi Malaysia, \\ Jln Sultan Yahya Petra, 54100 Kuala Lumpur, ${ }^{2}$ Negeri Sembilan State Health Depart., Jln Rasah, Bkt \\ Rasah, 70300 Seremban, Negeri Sembilan, ${ }^{2}$ Faculty of Business, Economics \& Social Development, \\ Universiti Malaysia Terengganu, 21030 Kuala Nerus, Terengganu Malaysia \\ Email: mahaza@ibs.utm.my
}

\begin{abstract}
Many organizations are interested in succesion planning in developing their talent. However, there are some challenges in practically implement the planning in talent development process. For instance, one of the most challenging issues in human resource management is dealing with employee turnover, retention and engagement. As high turnover employee is a bad sign as it will increase organization overall cost and time spending to train the new employees. So, these issues need serious attention from the organization as it highly associated with the successful of the organization. Therefore, this conceptual paper presents the determinant factors for employee retention in an organization and challenges to implement it within the context of Malaysian organizations. This paper provide a better understanding how organizations could identify new strategies to improve their employee retention program.
\end{abstract}

Keywords: Talent Management, Retention, Turnover Intention, Succession Planning, Career Development

\section{Introduction}

An organization requires their employee to work at the maximum potential benefit to achieve their organization goal and objectives. Employees are expected to fulfill the organization needs from the first day they report duty. Employees are valuable assets for an organization and could be labeled as life-blood of an organization (Sushma, 2014). The key success for a company not depend solely on the profit that they are making, but is the ability of the organization management to appreciate and motivate their employee to achieve maximum performance potential for the benefit of the organization (Steinmetz, Vries \& Tijdens, 2014). Employees' commitment will determine organization performance and survival. The human resource management role is to organize people in the 
organization so that they can perform their duty or work responsibility effectively. Their role is to provide strategy to the management for effective use of employee as business resources. Human resource management deal with recruitment, management and providing guideline to the manpower of the organization with 3 main functions which are operative, managerial and advisory function. The most challenging task is the operative function. They are responsible for recruitment of new employee, providing training and development to new and existing employee and providing benefits and compensation to the employee, regular monitoring and evaluation on employee performance and compliance with the law and policy (Wan, Sulaiman \& Omar, 2012). In current globalization, competition in industry and business becomes more competitive and it is affecting the human resource to remain competitive by attracting best and talented employee to work in their organization and keep the available employee for long term. Employee retention and employee engagement is one of the most challenging issues for human resource management. The objective of this paper is to identify the determinant factors for employee retention in an organization and challenges to implement it.

\section{Turnover and Employee Retention}

Employee turnover is defined by number or percentage of employee leaving an organization and are replace by new employees. Turnover intention is employee's intention or planning to leave their current position and seek for other alternative job in other organization. According to Tett \& Meyer (1993), they defined turnover intention as "a conscious and deliberate willfulness to leave the organization". There are 3 common categories of employee turnover; voluntary and involuntary; internal and external; skilled and unskilled employee turnover. Involuntary employee turnover is defined by termination of an employee due to bad performance absenteeism or violation of work place policy. Involuntary turnover is because it is not the employee decision to leave the organization. Voluntary employee turnover is employee own decision to leave the organization due to number of reasons. The reason could be due to personal issue, moved to new area or accepting new job from other employer. Internal turnover described as employee taking over new duties within the same organization while external turnover the employee leaving the organization and moved to a new workplace which is outside the organization. Skilled and unskilled employee, the turnover for unskilled employee is much higher compared to skilled employee but the company might easily find the replacement for unskilled employee with minor loss of productivity and performance compared to skilled employee.

Employee retention is defined as an effort of an organization to provide and maintain a working environment which will motivate the employee to maintain in the organization (Herman, 2005). Employee retention is very crucial in an organization as it will give many benefits to the company. Many companies nowadays are concern with employee retention policies by addressing their employees need to improve their work satisfaction stay in the organization for maximum period of time. Mita (2014) defined employee retention as a technique adopted by businesses to maintain an effective workforce and at the same time meet operational requirements. Bidisha (2013) described it as a process in which the employees are encouraged to remain with the organization for the maximum period of time or until the completion of the project. 
INTERNATIONAL JOURNAL OF ACADEMIC RESEARCH IN BUSINESS AND SOCIAL SCIENCES Vol. 10, No. 4, April, 2020, E-ISSN: 2222-6990 @ 2020 HRMARS

High employee turnover has a bad implication to the organization. The implication that an organization has to bear the burden is the cost. It is expected that the cost will be increased with increasing employee turnover. The cost that organization has to cover after losing an employee are hiring expenses, training and development, loss of sales and productivity during replacement search and retaining. The cost that incurred during hiring process include advertising cost, recruiter's salary, employee referral bonuses, travel expenses and $3^{\text {rd }}$ party recruiter fees. The cost of hiring new employee is depending on the types of industries. A few studies found that the estimated cost for employee turnover is about $20 \%-500 \%$ of those leaving employee's annual salary. High employee turnover can result in low workplace morale. This situation happen as the remaining employee will overwork as they need to take responsibility and task from the employee who left the organization. The affected employee will have extra workload and at the same time need to adapt and learn new procedure and work duties which will cause stress at workplace. If the situation persistently happens for long period, the affected employee will de-motivate and has intention to leave the organization. The employer will have problem to keep and retain high quality talent employee for long period. In addition, service and product quality will be affected by shortage of workforce. This is because lack of proper and complete training for a particular task or work duties by inexperienced employee. This shows the level of knowledge and experience loss suffers by organization as a result of employee turnover. This is posited by Urbancova \& Linhartova (2011), labour turnover results in an organization's inability to ensure knowledge continuity. High employee turnover will affects profitability of the affected company. This is due to rising in cost and lower productivity or revenue from loss of employee. The organization may need time to gain their profitability back or break even especially for a small company (Kotze \& Roodt, 2005) highlighted that losing good employee will affect the organization morale and may influence other employee as remaining employee will demotivated and decrease their work satisfaction. If this continues to happen, the employee will get distracted and might follow their colleague to leave the organization for new opportunity. High turnover is a bad sign and can be fatal to the organization especially small to medium firm due to shortage of expertise in the job market and high cost to train new employee. Dissatisfied employee are likely to have higher career plateau tendencies and intention to leave the organization compared to satisfied employee. Dissatisfaction leads to thoughts of quitting. This thought later make employee to seek for new opportunity or retain in current organization after weight the cost and benefit for each option.

\section{Current Situation on Employee Turnover and Employee Retention Globally and in Malaysia}

Based on the study by Mercer Webcast Series (2016), the average global voluntary employee turnover rate is $9.1 \%$. From the same study, it was found that top 5 countries with highest voluntary employee turnover rate is Argentina (16.8\%), Venezuela (16.7\%), Romania (16.5\%), Indonesia (15.8\%) and Philippines (15.5\%). The top 5 countries with lowest voluntary employee turnover rate are Slovenia (1.6\%), Finland (1.7\%), Greece (2.3\%), Puerto Rico (2.5\%) and Italy (2.8\%). Based on Hewitt's survey report, employee voluntary turnover in Malaysia is progressively increasing throughout the years from $9.3 \%$ in 2008, $10.1 \%$ in 2009 to $13 \%$ in 2010 . This shows that Malaysia has employee turnover trend higher than average global rate. This number should be taken seriously and need to be investigated. The highest group that contributes to voluntary turnover is $Y$ generation. This group of generation is known with their characteristic that is highly ambitious, always looking forward for 
professional growth opportunities, fast track career growth and desire for high salary. There is new culture among this young generation in Malaysia which job hopping is a common practice. Job hopping practices is driven by instinctive impulse rather than logical thought and the $Y$ generation group of employee has lowest loyalty towards the organization. They will hop on job everywhere and at anytime that will fulfill their ambition and needs.

\section{Employee Retention Statistic Globally and in Malaysia}

There is continuous growth for labor market in Malaysia. This favorable condition is due to good economic situation with increasing foreign and domestic investment. In Malaysia, employee turnover rate is increasing trend from $13.2 \%$ in 2014 to $14.3 \%$ in 2015 with manufacturing business is the most affected industry by high turnover rate among employee (Mystarjob, 2015). A biennial studies by 2014 Global Workforce Study (GWS) (2014) and 2014 Talent Management and Reward Study (TM\&R) (2014) by global professional services firm, Towers Watson (NYSE,NASDAQ:TW). The study is conducted through a survey which involved approximately over 32000 employees and 1637 organization globally which represents the full time employees working in mid to large size organization in a wide range of industries. The Malaysia sample includes over 1000 employees which conducted through online survey from April to May 2014. Overall, the employees who are highly engaged with the organization for year 2014 is still low at 40\%, consistent with the global average, despite small rising from $36 \%$ in 2012 . The main concern is the employee retention rate which shows worsening trend, more employees are saying they are likely to leave the organization within two years; from $29 \%$ in 2012 to $36 \%$ in 2014. Furthermore, there is increasing trend for highly engaged employees which they are likely to leave the organization within two years, from 30\% in 2012 to $31 \%$. According to Lim (2001), it is surprisingly reported that Malaysian employee are only willing to stay in an organization for a maximum of 3 years period, this finding show that Malaysian were an active job hopper.

\section{Top Driver for Employee Retention}

The online survey conducted by 2014 Global Workforce Study (GWS 2014) and 2014 Talent Management and Reward Study (TM\&R 2014) include question regarding employees opinion on the most priority factors to be consider to retain in the organization and the survey also asking question on employer what they believe to be the top factor for employee retention. 
INTERNATIONAL JOURNAL OF ACADEMIC RESEARCH IN BUSINESS AND SOCIAL SCIENCES

Vol. 10, No. 4, April, 2020, E-ISSN: 2222-6990 @ 2020 HRMARS

Figure 1: Top 7 factor for employee retention based on employee and employer perspective.

\begin{tabular}{|c|c|}
\hline Employer View & Employee View \\
\hline $\begin{array}{l}\text { - Base pay/ salary/ } \\
\text { compensation }\end{array}$ & $\begin{array}{l}\text { Base pay/ salary/ } \\
\text { compensation }\end{array}$ \\
\hline $\begin{array}{l}\text { Career } \\
\text { advancement } \\
\text { opportunities }\end{array}$ & $\begin{array}{l}\text { Career } \\
\text { advancement } \\
\text { opportunities }\end{array}$ \\
\hline $\begin{array}{l}\text { Relationship with } \\
\text { supervisor/ } \\
\text { manager } \\
\end{array}$ & $\begin{array}{l}\text { Trust and } \\
\text { confidence in } \\
\text { senior leadership }\end{array}$ \\
\hline $\begin{array}{l}\text { - Manage/ limit } \\
\text { work related } \\
\text { stress } \\
\end{array}$ & Job security \\
\hline $\begin{array}{l}\text { Learning and } \\
\text { development } \\
\text { oppoturnities }\end{array}$ & $\begin{array}{l}\text { Length of } \\
\text { commute }\end{array}$ \\
\hline $\begin{array}{l}\text { - } \text { Short term } \\
\text { incentives }\end{array}$ & $\begin{array}{l}\text { Relationship with } \\
\text { supervisor/ } \\
\text { manager }\end{array}$ \\
\hline - Challenging work & $\begin{array}{l}\text { Manage/ limit } \\
\text { work related } \\
\text { stress }\end{array}$ \\
\hline
\end{tabular}

Source: 2014 Towers Watson Global Workforce Study and 2014 Towers

Watson Global Talent Management and Rewards Study

Based on the Figure 1, the top 2 factor which is believe to be the reason for employee attraction is similar for employee and employer's view: base pay/ salary and career advancement. There is different view for employee and employer perspective for another 5 factors. The third top factor from employee's view is trust in senior leadership which is not listed in the top 7 from employers' view. This show many employer had underestimated the senior leadership impact on employee and overestimate impact of supervisor and manager. Indeed, both factors are equally important for a successful organization. The next important factor for employee retention is job security which was underestimated by employer as this factor was not listed under employer's view. This study is conducted globally and the result might be different for each company. The only reliable method to conduct the study is by doing a company specific survey to produce specific result for a specific organization.

Based on the study conducted by Towers Watson (2014), the main reason for employee intention to stay in the organization is base pay regardless of age (see Figure 2). The second most important reason is career advancement opportunities for employee age less than 50 years old. While for senior employee age more than 50, they cited trust/ confidence in senior leadership rather than career development. Career development ranked third. Advance age is the reason that career development 
INTERNATIONAL JOURNAL OF ACADEMIC RESEARCH IN BUSINESS AND SOCIAL SCIENCES Vol. 10, No. 4, April, 2020, E-ISSN: 2222-6990 @ 2020 HRMARS

is not important compared to trust in senior leadership as majority of employee retired at the age of 50-60 year old. The third top important reason for employee retention for young generation less than 30 years old is the length of commute. This group of generation prefers working nearby to their house. While, trust/ confidence in senior leadership is important reason for employee within age group of 30-49 years old.

Figure 2: Top 5 factors for employee retention based on employee age

\begin{tabular}{|c|c|c|c|c|}
\hline & $<30$ years old & 30-39 years old & $\begin{array}{l}40-49 \text { years } \\
\text { old }\end{array}$ & 50 years old \\
\hline 1 & $\begin{array}{l}\text { Base pay/ } \\
\text { salary }\end{array}$ & Base pay/ salary & $\begin{array}{l}\text { Base pay/ } \\
\text { salary }\end{array}$ & $\begin{array}{l}\text { Base pay/ } \\
\text { salary }\end{array}$ \\
\hline 2 & $\begin{array}{l}\text { Career } \\
\text { advancement } \\
\text { opportunities }\end{array}$ & $\begin{array}{l}\text { Career } \\
\text { advancement } \\
\text { opportunities }\end{array}$ & $\begin{array}{l}\text { Career } \\
\text { advancement } \\
\text { opportunities }\end{array}$ & $\begin{array}{l}\text { Trust/ confidence } \\
\text { in senior leaders }\end{array}$ \\
\hline 3 & $\begin{array}{l}\text { Length of } \\
\text { commute }\end{array}$ & $\begin{array}{l}\text { Trust/ } \\
\text { confidence in } \\
\text { senior } \\
\text { leadership }\end{array}$ & $\begin{array}{l}\text { Trust/ } \\
\text { confidence in } \\
\text { senior } \\
\text { leadership }\end{array}$ & $\begin{array}{l}\text { Career } \\
\text { advancement } \\
\text { opportunities }\end{array}$ \\
\hline 4 & $\begin{array}{l}\text { Manage/ limit } \\
\text { work related } \\
\text { stress }\end{array}$ & $\begin{array}{l}\text { Relationship } \\
\text { with supervisor/ } \\
\text { manager }\end{array}$ & Job security & Job security \\
\hline 5 & $\begin{array}{l}\text { Trust/ } \\
\text { confidence in } \\
\text { senior } \\
\text { leadership }\end{array}$ & $\begin{array}{l}\text { Length of } \\
\text { commute }\end{array}$ & $\begin{array}{l}\text { Relationship } \\
\text { with } \\
\text { supervisor/ } \\
\text { manager }\end{array}$ & $\begin{array}{l}\text { Relationship } \\
\text { with } \\
\text { supervisor/ } \\
\text { manager }\end{array}$ \\
\hline
\end{tabular}

\section{Determinant Factors for Employee Retention}

According to previous research and studies conducted, the factors contribute for employee retention is not determined by a single issue but contribute by multiple factors. According to Kossivi et al (2016) employee retention factors include compensation; career development opportunities; work-life balance; management and leadership; work environment; social support; employee autonomy; training and development.

\section{(i) Compensation}

Compensation is total cash and non cash payment that is offered to the employee by employer in exchange of what he/ she had performed to the organization. Compensation is more than regular paycheck or salary as it includes other benefits. Compensation includes regular salary wages, sales commission, overtime claim, mileage claim, bonus pay and other benefits such as insurance, off day, times off claim; and retirement schemes. There is unclear relationship between pay and compensation with employee retention. There is research that suggest there is direct relationship between compensation and retention (Hytter, 2007) while other research does not say so (Kossivi et al, 2016). Compensation is important for employee retention as the compensation will motivate and 
INTERNATIONAL JOURNAL OF ACADEMIC RESEARCH IN BUSINESS AND SOCIAL SCIENCES Vol. 10, No. 4, April, 2020, E-ISSN: 2222-6990 @ 2020 HRMARS

encourage employee to perform well in the organization. This is support by (Millers and Wheeler, 1992) as they stated that one of the reasons to keep an employee to stay in the organization is better compensation and benefits (Teseema and Soeters, 2006), they noticed voluntary turnover is high among employee who valued higher financial reward as their compensation package. According to (Shepherd and Mathews, 2000) talented employee tends to be highly paid based on their ability and skill. In addition, there is suggestion by Jo (2008) that organization should consider monetary incentives such as increase base pay and bonuses if the employee decided to leave the organization for another work to get more money and offer non monetary incentives such as awards or other benefits if the employee decided to leave for non money reason. In many cases, offering non monetary rewards is enough to retain the motivated employee and reduced the labor cost. Employer should never ignore compensation and benefits for employee when planning framework to attract and retain their best and talented worker. Even though compensation and benefits play a major role in employee retention as it was ranked as top one factor for employee retention for both employee and employers' view, but compensation alone is not an important factor for employee to retain in the long term. Leigh Branham, CEO of Keeping the People, notes that 89 percent of managers believe people leave their jobs due to compensation, but 88 percent of employees actually leave for other reasons. Improved in compensation and other benefits will retain employee in a short term. To remain them in the long term, they organization should improve compensation couple with other factors such as improved work life balance and work related stress.

\section{(ii) Career development opportunities}

Career development is an on-going process or series of activity in career advancement. It involves training on new skills, promoted to higher level of responsibility and transition to different work scope or organization. Every employee working in the organization will look forward for career development in the right direction based on their personal goals and objectives. Wan \& Omar (2012) state that the fairer promotional opportunities are, the higher the commitment of employee towards the organization. Companies are recommended to provide fair promotion opportunities to their employee to increase the organization commitment level. Employee with high commitment level will have less intention to leave the organization. There are many researches support the career development with employee retention. Horwitz et al (2003) suggested that personal and professional growth with career advancement opportunities given by employer will increase employee commitment to stay. Arnold (2005) and Herman (2005) posited that there is direct relationship between career development opportunities with retention. According to Moncarz et al (2009), employee retention rate is high when there is proper and persistent training given to them. Vimala (2012) found that there is positive relationship between career development opportunities and employee intention to stay in Kedah State Development Corporation company, the employee believe that the employer giving them better career opportunities compared to outsiders and employer able to provide them with a clear career pathway. According to Mano-Negrin \& Tzafrir (2004), employees will actively searching for an alternative work in the external market if the organization that he works failed to provide a substantial opportunities growth for their career advancement. 
INTERNATIONAL JOURNAL OF ACADEMIC RESEARCH IN BUSINESS AND SOCIAL SCIENCES Vol. 10, No. 4, April, 2020, E-ISSN: 2222-6990 @ 2020 HRMARS

\section{(iii) Senior Leadership}

Trust and confidence in senior leadership is important determinant factor for employee retention as it ranked third top common reason for retention from employee perspective view. There are 2 types of leadership styles, transformational and transactional leadership. Transformational leadership is characterized by a leader who creates vision to guide the subordinate the change through transformation and inspiration. This leadership style is sometimes call quiet leaders and one of the most inspiring leadership styles. While transactional leadership style is characterized by a leader who expecting the subordinate to carry out their duties based on leader instruction. They will given reward if able to carry out the duties well and given punishment if failed to do so. In the study carried by Bycio et al (1995) found that the higher degree of transformational leadership the lower the intention to leave the organization. Wells et al conducted a different study to investigate relation between leadership styles (transformational and transactional leadership) and employee retention. The studies reveal that both leadership styles have positive effect on employee retention. This is supported by McNeese-Smith (1995)'s study which found that leadership has strong constructive relationship with employee commitment toward organization and employee job satisfaction. Employee intention to stay in the organization might dependable on human factor especially leadership rather than organization itself. Employees are human, and being a human any emotion related will greatly influence the decision making. Poor leadership will cause employees stress and emotional exhaustion if happen for long period of time; decrease the employees' motivation and commitment towards organization and intention to leave the organization.

\section{(iv) Relationship with supervisor and manager}

Relationship with immediate supervisor or manager is ranked third top factor for employee retention based on employer's perspective. Having a good relationship with the supervisor will have positive impact on employee intention to stay in the organization. A good relationship will influence the employee as subordinates to perform work, maintaining good communication and cooperation with the supervisor. Sutherland \& Jordaan (2004) state that relationship with immediate supervisor is identified as top 10 most important factor for employee's intention to stay. This is supported by Eisenberger et al. (2002) which relationship with supervisor has an impact on employee retention. Considerate leader will make employee to stay longer in the organization. Any employee working in any organization has a will to work with trustful and respected supervisor, understand them and treat them with good manner. A good relationship with supervisor has indirectly contributes to other positive value such as receive a good supervisor support and motivates to perform better in the future. The good support could be in term of guidance, advices, feedback, acknowledgment etc. This will create work environment less stress, improve job satisfaction, increase commitment level and reduced the voluntary employee turnover. Supervisor showing gratitude and appreciation for employee contribution will motivates them to perform better and underappreciated will make employee feels down and demoralized, and will have intention to leave the organization.

\section{(v) Job Security}

Job security is ranked fourth important factor for employee retention based on employees' view. Katou \& Budhwar (2007) state that job security is very important factor to be consider among employee in a country with high unemployment rate. Job security also plays an important factor 
during economy or financial crisis as employee need a stable employment to keep on living. A study conducted by Alif et al (2017) to investigate relationship between career development and job security with employee loyalty at luxury resorts in Terenganu. The finding of this study is, there is positive correlation between career development and job security with employee loyalty. It is important for the organization to provide job security so that the employee would feel satisfaction working and secure steady employment.

\section{(vi) Work Related Stress}

Work related stress is common and naturally present in the organization. Stress that arises from the work will cause either positive or negative impact on employee. A certain level of stress can be helpful as stress can acts as a motivator to accomplish goals. Some of bad impact that could happen from the stress is absenteeism, work dissatisfaction, in-effectiveness and turnover. These implications are more likely happen for short term and the implication will back to normal once the cause of stress is removed. Long term implication of work related stress can be serious and affect individual function. Long standing stress that is not properly managed will affect individual health such as hypertension, heart attack, stroke, depression, anxiety and obesity. This will affect organization in term of covering for medical cost and operating cost. Covering for employee medical cost is highly expensive especially chronic disease as they are required for frequent follow up and continuation of medication. In term of operating cost, organization need to find replacement if the employee is on medical leave. They are multiple cause of work related stress (Sushma, 2014). List of common causes of work related stress are working condition, personal characteristic, compensation, workplace relationship and organizational culture.

\section{Length of Commute}

Commuting distances between employee's house and work place have an impact on employee work satisfaction and intention to stay in the organization. Commuting stress may result in negative implication to individual psychological states such as frustration, depression, anxiety and time pressure. This negative effect will subsequently affect employee performance and work satisfaction. Employee feeling of overwhelmed and might experience reduced in quality of work life as they are struggling to meet work-related expectations because of long distance commuting. According to Grandey \& Cropanzano (1999), employee who experience high levels of commuting stress will reduce the stress by quitting from the current work. The decision to quit from the cuurent work is consider coping mechanism in response to commuting stress. Zax and Kain (1991) found that the longer the distance to go for work, the greater the intention to leave the current work, and at the same time continue to live at current housing area. This suggests that employee would leave the current organization rather that move out from their house to live nearby to current work place. Similar finding is seen in study by Steinmetz, Vries, \& Tijdens (2014). This study found that if employee have to travel long journey to make an effort for physically report to work, they will unlikely to stay in the organization.

\section{Challenges in Employee Retention}

Base pay and salary are the top reason for employee to stay in the organization. Retention of the employee will be major problem when employee request for an exceptionally high salary, which is 
beyond capability of the organization. Every organization has own salary budget for the employee which can be raised but not beyond certain limit. Selection of potential candidates to fill the vacant position plays important role on the future of the organization. Hiring wrong candidates will give bad implication to the organization as candidates speak all kind of lies during job interview session, which later turn out that there has been a mismatch between job scope and employee needs and thus has intention to quit and looking for another job. Majority of the employee will get bored after few years of handling same task. The work might be interesting and challenging at initial phase, but after few years it could become less interesting. The organization should offer job rotation for them to try new work experience. If an organization fails to do so, the employee might consider leaving the organization looking for new work experience.

\section{Recommendation}

This paper has discussed and finds out the determinants factors for employee retention. There are few strategies need to be applied by human resource management to better retain their talented employee and reduced implication from high employee turnover. The strategy that can be applied is employee retention program. The definition of effective employee retention program is a systematic effort to create and foster an environment that encourages employees to remain employed by having policies and practices in place that address their diverse needs which include long list of factor for employee retention. This program sound easy to perform but actually a difficult task to carry out. Another strategy by the manager or immediate supervisor is to keep their subordinates highly motivated at workplace by fulfilled their needs. Employee engagement is another strategy should be carry out by the organization to keep their talented employee working with them for long period. Employee that is engaged is someone who is fully involved, committed and enthusiastic about their work. This highly engaged employee will care about the future of the company and looking forward to perform better to make sure success of the organization. Many organizations more focus on allocation of their resources on external branding front, meanwhile they neglecting the internal environment, failing to provide engaging, challenging and appealing work environments. Employee engagement can be achieved in many ways. Example celebrate achievements to motivate employee to perform better, this celebration will show that the firm is appreciate much their employee hard work and will create a feeling of enjoyment for them to continue working with the firm. Not to miss out celebrate people for their birthday, retirement and newcomers to show to them that they matter. Another great way for employee engagement is to get the employee and their family gathers in informal event such as team building, family day and annual dinner. Working for minimum of 8 hours per day for 5-7 days can be overwhelming. Getting employee joining such activities will create a closer relationship with their subordinate, colleague and supervisor and will improve communication between them. Give and getting employee feedback is also important to create understanding between each other and improve any shortfall. Having profit sharing scheme is also a good way to retain their employee as it will benefit every employee for their contribution in the organization.

\section{Conclusion}

To keep their talented employee is a major issue face by majority of organizations around the world. It is a great lose for an organization to lose their talented employee and furthermore losing their employee to the competitor. The factors that contribute to employee intention to stay in certain 
organization are multi-factorial. These factors could be varies between different countries, types of industries, different firms and between different departments within a firm. Keeping their talented employee as long as possible is crucial for the success of the organization as higher employee turnover will have negative implication on the organization operating, service and financial performance. The human resource of the organization are responsible to report to the higher management regarding their employee turnover and employee retention statistic for them to make a comprehensive study to find the determinant factors to keep their talented employee. This issue should be closely monitored to minimize the negative impact on the organization liabilities. The best concept to tackle this issue is by taking care of their employee's needs. New strategies such as improvement in employee retention program should be established immediately after the cause of employee intention for leaving is determined.

\section{References}

Aliff, M. (2017) Career Development, Job Security and Employee Loyalty at a Luxury Resort in Terengganu, Malaysia, International Journal of Academic Research in Business and Social Sciences, Vol (7, No 10), 667-674.

Arnold, E. (2005) Managing Human Resources to Improve Employee Retention. Health Care Manager, 24, 132-140.

Bidisha, L. D., and Mukulesh, B. (2013) Employee Retention: A Review of Literature. Journal of Business and Management, 14, 8-16.

Bycio, P., Hackett, R., and Allen, J. (1995). Further Assessment of Bass's (1985) Conceptualization of Transactional and Transformational Leadership. Journal of Applied Psychology, 80: 468-478

Horwitz, F. M., Heng, C. T., and Quazi, H. A. (2003) Finders, Keepers? Attracting, Motivating and Retaining Knowledge Workers. Human Resource Management Journal, 13, 23-44.

Hytter, A. (2007) Retention strategies in France and Sweden. Irish Journal of Management. 28(1). p.59-79.

Jo, V. H. (2008). Voluntary Turnover and Women Administrator in Higher Education. High Educ, 56, 565-582.

Katou, A., \& Budhwar, P. (2007). The effect of human resource management policies on organizational performance in Greek manufacturing firms. Thunderbird International Business Review, 49(1), 1-35.

Mano-Negrin, R., and Tzafrir, S. S. (2004). Job Search Modes and Turnover. Career Development International, Vol. 9, No. 5, pp.442-458.

McNeese-Smith, D. (1995). Job Satisfaction, Productivity, and Organizational Commitment: The Result of Leadership. Journal of Nursing Administration, 25(9), 17-26.

Miller, J. G., \& Wheeler, K. G. (1992). Unraveling the mysteries of gender differences in intentions to leave the organization. Journal of Organizational Behavior, 13(5), 465-478.

Mita, M., Aarti, K., and Ravneeta, D. (2014) Study on Employee Retention and Commitment. International Journal of Advance Research in Computer Science and Management Studies, 2, 154-164.

Sushma, R. (2014) Effects of Job Stress on Employee Retention: A Study in Context of Indian Industries. Lucknow. International Journal of Research in Management, Science \& Technology. Retrieved from http://ijrmst.org/download/vol2no2/sushma.pdf 
INTERNATIONAL JOURNAL OF ACADEMIC RESEARCH IN BUSINESS AND SOCIAL SCIENCES

Vol. 10, No. 4, April, 2020, E-ISSN: 2222-6990 @ 2020 HRMARS

Teseema, M., Soeters, J. (2006). Challenges and prospects of HRM in developing countries: testing the HRM performance link in Eritrean civil service. International Journal of Human Resource Management. 17(1). p.86-105.

Grandey, A. A., \& Cropanzano, R. (1999). The conservation of resources model applied to workfamily conflict and strain. Journal of Vocational Behavior, 54(2), 350-370.

Herman, R. E. (2005) HR Managers as Employee-Retention Specialists. Employment Relations Today, 32, 1-7.

Lim, L. (2001). Work Cultural Values of Malays and Chinese Malaysians. International Journal of Cross Cultural Management, 1(2), 209-226.

Moncarz, E., Zhao, J., and Kay, C. (2009) An Exploratory Study of US Lodging Properties' Organizational Practices on Employee Turnover and Retention. International Journal of Contemporary Hospitality Management, 21, 437-458.

Mystarjob. (2015). Salary to increase for Malaysians in 2015 - Career Guide myStarjob.com.

Retrieved from http://mystarjob.com/articles/story.aspx?file=/2013/12/7/mystarjob_careerguide/1396878 $2 \& \mathrm{~s}$ ec $=$ mystarjob_careerguide

Steinmetz, S., Vries, D., \& Tijdens, K. G. (2014). Should I stay or should I go? The impact of working time and wages on retention in the health workforce. Human Resources for Health, 12(1), 23.

Sutherland, M., \& Jordaan, W. (2004). Factors Affecting The Retention Of Knowledge Workers. SA Journal of Human Resource Management, 2(2), 55-64.

Tett, R. P., and Meyer, J. P. (1993). Job satisfaction, organizational commitment, turnover intention, and turnover: Path analyses based on meta-analytic findings. Personnel Psychology, 46(2), 259-293.

Urbancová, H, Linhartová L. (2011). Staff Turnover as a Possible Threat to Knowledge Loss. Journal of Competitiveness, 3, 84-98.

Wan, H., Sulaiman, M., \& Omar, A. (2012). Procedural justice in promotion decision of managerial staff in Malaysia. Asia Pacific Business Review, 18(1), 99-121.

Wells, J. E., and Peachey, J. W. (2010). Turnover intentions: Do leadership behaviors and satisfaction with the leader matter, Team Performance Management, 17: 23-40

Zax, J. S., \& Kain, J. F. (1991). Commutes, quits, and moves. Journal of Urban Economics, 29, 153165. 